\title{
EDUCATING EUROPE: An analysis of EU Educational Policies ${ }^{1}$
}

\author{
Antonio Novoa \\ (University of Lisbon) \\ William deJong-Lambert \\ (Teachers College, Columbia University, New York)
}

This chapter analyses educational policies in the European Union. Because the Unionization $^{2}$ process is taking place on so many different levels - ranging from the local to the national, and the national to the global (and vice-versa) - it is possible to undertake this project with reference to any number of dimensions. This task is also complicated by the interconnected processes of Europeanization and globalization, as well as the temptation to oppose nation-states to the European Union, "localism" with "cosmopolitanism", etc. (Bauman, 2001; Breckenridge et al., 2002). The layer which we have chosen intends to build the European Union as the main explanatory level of analysis. In fact, it is necessary to determine the nature of this unprecedented political entity, in order to apprehend its influence in the formulation of educational policies. Adopting this perspective, we hope to displace and replace ourselves in the European political debate, opening the possibility for new questions and understandings.

1 The first draft of this text was written while I was a visiting scholar at the University of Oxford (Michaelis Term, 2001). The final version was concluded in the year 2002, as a Visiting Professor at Teachers College, Columbia University (New York), a stay which enabled a collaboration with William deJong-Lambert, a PhD student in Comparative Education. I wish to thank my colleagues for an intellectually productive and challenging time, as well as the Fulbright Foundation which granted me a scholarship for my stay in New York (January-June, 2002).

${ }^{2}$ We are using the term "unionization” to refer to the myriad of processes involved, at every level, in the creation of the European Union. 
Too often there is a tendency to participate, without pause for critical reflection, in the programmes and initiatives originating from Brussels. Our intention is to consider European educational policies as an object of study, in the general context of political organisation within the European Union. The point of departure is a metaphor, articulated by the EU Spanish Presidency (first semester of 2002), that education is to be considered as the fourth pillar of the European construction. Building metaphors are a fixture of the language circulating with reference to EU process - the (re)construction of Europe. Frequent references to "laying foundations" and the idea of a "common house", are coupled with descriptions of policymakers as "architects" and "masons”, even as Europeans themselves are portrayed as "onlookers" who must "wait" until the process is "completed before they can appreciate its quality" (Commissioner for Economic and Monetary Affairs, Yves-Thibault de Silguy, cit. in Shore, 2000, p. 2). We could add other metaphors found throughout EU texts: walls, benchmarks, barriers, as well as various metaphors of "space" and "circulation". The popularity of metaphors is obviously related to the fact that the European Union has not strong political roots and locations, and needs to compensate it with an appealing rhetoric and mobilizing images. Not all metaphors, however, are equally useful or captivating. As Evelyn Keller explains in her work about biology: "The effectiveness of a metaphor, like that of a speech-act, depends on shared social conventions and, perhaps especially, on the authority conventionally granted to those who use it" (1995, pp. xi-xii).

The reference to education as a fourth pillar is thus a conceptually meaningful move, signifying an attempt to isolate education policy as primary in the context of EU policy-making. It is this important transitional moment which we will attempt to grasp in our text. We begin in the first section with an introduction to the current state of European affairs, moving from the debates of governance to issues of citizenship and the role played by education. The second section deals with the concept of the European educational space, wherein we use a metaphor of "states of matter" to describe the evolution of educational policies, particularly post-Maastricht Treaty. Finally, the last section we focus on the Detailed work programme on the follow-up of the objectives of education and training systems in Europe, approved in 2002, arguing that it establishes a new tempo for European educational policies. The text closes with a codetta, advocating for the presence of critical thinking in the European space - a thinking which avoids the acceptance of Unionization as inevitable. Such fatalism, together with the feeling that "things" are happening independently of the will of European citizens, can lead to a disenchantment with politics, which could transform reverie into nightmare. 


\section{THE STATE OF THE EUROPEAN AFFAIRS}

This paper starts a process responding to the disenchantment of many of the Union's citizens. Alienation from politics is not just a European problem, it is global, national and local. But for the Union it represents a particular challenge. Given the deep level of integration already achieved, people have similar expectations for the Union as they have for domestic politics and political institutions. But the Union cannot develop and deliver policy in the same way as a national government (European Governance - A White Paper, 2001, p. 32).

Recent debates on European Governance have been characterized by a malaise about the present situation, and a sense of disillusionment with regard the future of Europe. An "heroic" account of the European past is defined in terms of a longue duree, from which a contemporary heritage is derived, as well as a recent past, originating in post-War prosperity and producing half a century of peace and progress. However, one can still determine a definite alienation from politics and disenchantment with the European project. This juxtaposition of opposing attitudes requires an understanding of the amalgamation of discourses and complexity of networks, operating throughout the European space. The White Paper on European Governance is constructed in terms of openness, participation, accountability, effectiveness and coherence; nevertheless we believe that it in fact accentuates the "opacity" of the European Union, namely in terms of the incapacity to understand the decision-making processes and the role of the different national, sub-national and supra-national institutions.

The political crisis with regard to the way in which policy is implemented is also a "crisis" in the intellectual thinking, that is in the way in which Europe is discussed and apprehended. This debate takes place in a language strongly influenced by the media and by an expert-discourse that tends to homogenize "problems" and "solutions" (Novoa, 2002). A first tendency, is evident in the setting of the political agenda by the media, with a recurrent dramatization of educational matters, in which the portrayal of problems and the framing of questions is used as a method of imposing solutions. An "instant democracy" is forged according to opinion polls and public surveys, creating the "society of the spectacle", to use the concept coined by Guy Debord. This latter notion has been characterized by Michael Hardt and Toni Negri as the construction of an artificial coherence, a spectacle which while in fact orderless, "functions as if there were (...) a point of central control" (2000, p. 323). The exposure to "objective" estimators of public opinion transforms politics into public spectacle, negating the possibility for critical discussion.

A second tendency, that in part overlaps the previous one, is represented by the figure of the expert, and the circulation of a discourse in a transnational mood. The mobilization of experts circulates a rootless, location-less, international discourse. We are thus presented with a "new Babel”, consisting of terms including "globalization”, "flexibility”, "new economy”, 
“zero tolerance”, “multiculturalism”, etc. (Bourdieu \& Wacquant, 2000). Dressed in an impressive "moral conformity", there is an interesting unanimity in this debate, that uses recurrently terminology such as rigor, efficiency, accountability, responsibility, autonomy, market, choice, and customers, to address educational matters. The diffusion of these concepts necessitates that they be banal enough to be universally accepted as solutions for every problem. As empty rhetoric they create the illusion of a common agenda which, because it belongs to no one, can be described as belonging to everyone.

In recent years a large amount has been written on EU issues. This literature has however more often been obfuscating than illuminating, not only because the authors become lost among the myriad of institutions and levels of decision making, but also because they adopt (implicitly or explicitly) a position pro or contra EU policies. From our perspective it is necessary to move from traditional explanations, embedded in "international relations" or institutionalist approaches, and adopt more sophisticated conceptions underpinned by historical and comparative thinking. Peter Van Ham refers to our present epoch as one in which "geographical entities are less fixed and (most) no longer seem to control their destiny" (2001, pp. 1-2). He therefore criticizes dichotomous conceptions of International Relations as incapable of providing us with an understanding of the changing political, social, economic and cultural landscape. We will argue that governance, as the central concept that has been used in current discussions about the EU, cannot be taken for granted and must be critically analyzed. In fact, as Mathias Albert puts it: "It may very well be that it is exactly the advances made in theorizing about governance (without government) that are part of the problem for advancing the theorizing about democracy in the European context, because it has led analysis away from the state too soon, trying to adopt new notions of legitimacy for new forms of governance without taking sufficient account of what can and must be legitimized democratically" (2002, p. 296). The reference to "multi-level governance", and other related terms, can be understood as a strategy to avoid a political discussion, situating the debate in a diffused level of networks, agreements and partnerships without clear legitimacy. This is why there is a concern with the democratic deficit of the European Union, an issue which we will discuss in relation to governance in the next section of this paper.

The European Union is a political system in transformation, a process that is best understood as “experimental” (Wallace, 2001, p. 581). It is obvious that this process cannot be viewed through the lens of traditional politics. Laura Cram makes an important point when she notes that the European Commission has in the past been most effective when it substitutes grandiose claims for quiet and effective action (2001, p. 783). However, this notion of a "banal Europeanism” does not mean we should concede democracy to new forms of power, exercised by un-elected bureaucrats and professional experts. The criticism raised by Casey and Rivkin should be taken into consideration, when they point out that the European Commission is the most powerful EU institution: "This unelected and, for all purposes, unaccountable body has 
embarked on the creation of a unified European state, wherein it is the single most powerful institutional actor. With remarkable candor, the European Commission has admitted (...) that this very lack of accountability has been the secret of its success” (2001, pp. 47-48).

A linear account of the EU is not capable of mapping a political space, composed of various policy arenas, levels of decision-making and institutional arrangements. The sophistication required to do so need not imply a further "confusion" of political life, an opacity that functions as an obstacle to participation at the level of citizenship. It is this which causes erosion in the European process, creating distress and resistance towards that which is understood only as inevitable or ineluctable. Thus we must be cautious, and conscious of underlining the importance of "civic participation" and "social movements" in the transformation of Europe. To view them as "anachronistic", or to perceive opposition to neo-liberalism as "regressive", can be understood as part of a conservative revolution, which Pierre Bourdieu describes as a "strange revolution that restores the past but presents itself as progressive, transforming regression itself into a form of progress” (2002, p. 65).

\section{Governance and the "democratic deficit"}

Literature on the "democratic deficit" of the EU has been growing in recent years (Decker, 2002; Sweet, Sandholtz \& Fligstein, 2001). It is not our intention to insist on this issue, although the claims formulated by Jürgen Habermas (2001) for a "European-wide public sphere" are present in our thinking. We join Hellen Wallace in proposing that the debate "navigate" between understanding Unionization as "intergovernmentalism" versus those who understand it as a process of "fusion". As she concludes: "A more satisfactory analysis must surely lie in a better understanding of the push-pull between the European and country levels of politics and governance" (Wallace, 2001a, p. 15). Thus we refer to a "process that is itself about processes" - the open method of coordination. ${ }^{3}$ The open method, as it was devised at the Lisbon European Council in 2000, relies upon forms of comparative method such as "benchmarking, targets and scorecards, policy audit, and the potential for policy transfers" (Wallace, 2001, p. 591). While it has been constructed through the idea of governance, it is important to understand that its popularity resides precisely in its imprecision and ambiguity: "It has at least six uses, referring to: the minimal state; corporate governance; the new public management; 'good governance'; socio-cybernetic systems; and self-organising networks” (Rhodes, 1996, cit. in Cram, 2001a, pp. 598-599). Our argument is that this method is being

3 "The term open method of co-ordination stems from the Lisbon European Council (...). The emphasis is on consensus-forming with three elements of the economic situation; agreement of the appropriate economic policy response; and acceptance of peer pressure and, where necessary, adjustment of the policies being pursued" (Hodson \& Maher, 2001, p. 723). 
implemented in new policy areas, like education, defining a kind of "regulatory state" at the European level (Roberts \& Springer, 2001). It is possible to identify two major consequences, related with political discussions and more "technical” issues of decision-making, as we will explain below.

It has been pointed out that a European demos, in the sense of a population that feels itself to be one, is non-existent, thus it seems evident that, as Anthony Giddens has written, we require "democratizing of democracy” to avoid the structures of inequity (old-boy networks, racism, sexism, corruption) present in most democratic societies, and also in EU institutions (2002, p. 168). The question should not be raised exclusively in terms of the "constitutional argument", or with reference to "social contracts", but in terms of inventing new forms of political affiliation and commitment, not modeled on the institutions of the nation-state (Bellamy \& Warleigh, 2001, p. 10). Often the principle of subsidiarity is presented as an example of a strategy to consolidate cohesion and proximity in the process of decision-making. This argument has merit, yet we cannot ignore the counter-argument, presented by Lee Casey and David Rivkin who, after quoting the definition of subsidiarity given by Pascal Lamy (European Commissioner for Trade), ${ }^{4}$ reverse the perspective from which the principle of subsidiarity is intended to be understood, maintaining that it is rather a way of removing from "popular politics" matters that are to be decided at the European level. This is why the political legitimacy of the EU depends as much upon the efficiency of outcomes, as the process by which those outcomes are achieved. As Mark Kleinman has stated: "More attention will need to be given to the political and constitutional underpinnings of integration - and as a result, politics may re-emerge from the shadow of the economics” (2002, p. 223).

4 "The principle by which we tackle subjects as the right level which means as close to the man in the street as possible. We should only transfer to a higher, or more general, political body those questions which individuals, families, villages, regions, actions cannot decide for themselves" (cf. Casey \& Rivkin, 2001, p. 49). 
Another quite different way of addressing this issue of the "democratic deficit" is through the implementation of strategies of decision-making that rely on a more technical approach. It is necessary to emphasize the implications of the EU's affinity for depoliticisation by delegation to policy networks: "When a policy decision point approaches, but clashes between rival advocacy coalitions causes impasse, the EU's natural propensity is to depoliticise issues and 'push' them back to the sub-systemic level for quiet resolution" (Peterson, 2001, p. 309). A diversity of strategies - benchmarking, target-setting, peer review, expert networks, performance indicators, etc. - are mobilized in order to distract discussion from political issues, and reorient them towards the more diffuse level of governance. The "regulatory state" is thus implicated as an "evaluative state" as well, when elements of the market economy are brought into the public sector, and government use of incentives and performance indicators replaces "central planning and detailed regulation" (Van Heffen, Kickert \& Thomassen, 2000, p. 5). This transformation has great implications for education because the "Europeanization of education" is based on this method of establishing standards and benchmarks, enforcing the illusion that each country is free to follow its own path. According to the secretary general of the European Round Table of Industrialists, this institution played an important role in promoting benchmarking as a tool for guiding EU policies: "The idea was to establish criteria relevant to competitiveness and then publish figures in a regular and systematic way that would encourage each country to try to catch up with the best practice elsewhere, but without dictating the specific policy measures needed" (cf. Sisson \& Marginson, 2001, p. 2).

In fact, despite the illusion of autonomy, standards are pervasive mechanisms of governance, guides for how to behave and for judging behavior (Abbot \& Snidal, 2001), which must not be taken for granted. In 1999 the President of the European Commission declared "We are all benchmarkers now", indicating the degree to which this practice has replaced legal regulation or collective bargaining as the primary engine of Europeanisation (cf. Sisson \& Marginson, 2001). Though standards and benchmarks are presented as being based on some neutral, consensual and objective definition of best practice: "Everyone has known for ages what 'best practice' is, i.e. some form of semi-autonomous team working, backed up by 'bundles' of 'high commitment management practices', such as training, extensive two-way communication systems and employment security” (Sisson \& Marginson, 2001, p. 3). Nevertheless, the question must be raised: Who marks the bench? (cf. Kastrinos, 2001). Absent this question we embark on a kind of mystification, leading to a de-politicisation certain to increase the feeling of "inevitability" in European affairs and lack of "presence” of European citizens. To avoid such a condition we must move beyond rhetoric and the fragmented appeal to participation and active citizenship. Rather we should, as Pierre Bourdieu has contended, strengthen social movements as part of a process of inventing another kind of state, because "contrary to the neoliberal perspective, all social gains have historically come from active struggles” (cf. Grass \& Bourdieu, 2002, p. 66). 


\section{Nation-Europe, and Citizenship}

Since the fall of the Berlin Wall an intense debate has been taking place concerning nation-states and globalization (Smith, 2000). It is worth referring to two different perspectives in this debate: first, the assertion that "nations do not make states and nationalisms but the other way around" (Hobsbawm, 1990, p. 10); and second, the fact that "a growing cosmopolitanism does not in itself entail the decline of nationalism” (Smith, 1991, p. 176). These two points may inform an analysis of the European Union because it is obvious that we are witnessing an attempt to create supra-national regulations with what we could refer to as a "transnational state" (Robinson, 2001). It is also obvious, however, that as an intergovernmental structure, the EU is contributing to a strengthening of the nation-state (Brubaker, 1996). The ambiguity of this "hybrid form", existing somewhere between the nation-state and the phenomenon of globalization, is what makes EU studies so complex. Thus there is the risk of "homogenizing" the European space, ignoring cultural, historical and economic differences among individuals and countries, North, South, East, West, center and periphery. In this instance we end up with a mythical construction of nation-Europe, an entity filled with an "excess of past" and an "excess of future”.

Despite theory and the complexity of contemporary politics, there is still the idea of transposing to the European level a nineteenth century concept of Europe, subliminally present in most debates (Andrew, Crook \& Walker, 2000). It is perhaps an oversimplification, but one can perhaps identify two different strategies in this regard: a pragmatic approach, related to the "banal Europeanism" referred to above, and an identitarian approach, embedded in a conception of "heroic Europeanism” (Cram, 2001; Nevola, 2001). Though these two strategies are often mixed in programmes and political initiatives, they are still analytically useful in grasping different processes and tendencies. Anthony Smith highlights the "scant justice" done by post-modern analyses of the nation-state and describes the differences between those who believe in the idea of "national identity" versus those who have ceased to believe that such a concept is either viable or desirable. In both cases, attempts are made to inspire a sense of "being" and "feeling" European. Is the European Union merely a "condominium of powers" (Smith, 1991, p. 153), or "can love of Europe as patria be engineered" (Shore, 2000, p. 3)? Most important is perhaps Foucault's question: "What makes a Nation (in this case the so-called Nation-Europe) entitled to ask someone to die for it” (cf. Lotringer, 1996, p. 415).

The pragmatic approach tends to emphasize the conditions necessary to integrate the "European idea" into the quotidian details of individual experience. The customs union and the single market, demarcated by the abolition of internal frontiers within which circulates a single currency. The elements defining this approach are in the recent white paper on European Governance, with the implementation of policy orientations towards: use of accessible 
language; promotion of wider participation; greater clarity and responsibility; greater flexibility and effectiveness; overall policy coherence. As we will see in the next section, this same orientation also influences education policy. The adoption of "networking" and "benchmarking" tools is part of this process as well, along with the establishment of uniform statistics, the organization of comparative schemas, the creation of new Euro-symbols and concurrently, the rewriting of history - even if, as Ernest Renan said, "getting its history wrong is part of being a nation" (cf. Hobsbawm, 1990, p. 12). Thus we demarcate a shared territory with the identitarian approach, which legitimizes itself through the definition of a "European heritage".

In fact, the attempts to invent this "heritage", which characterize the identitarian approach, have proved deceptive and disappointing. As Jürgen Habermas argues, the identity of the European Union should be developed around "civic values", rather than some elusive "common heritage" (Giddens, 2002, p. 168). This "heritage” is typically constructed around a kind of civilisational thinking, stressing Greco-Roman or Judeo-Christian heritages as the lay foundation of Europe. In this instance the European Union is grounded in an ahistorical, "unitarian past", which simultaneously suggests a "grandiose future". Thus the popularity of the strategic goal which the EU has set for itself of becoming "the most competitive and dynamic knowledge-based economy in the world". This intention, articulated during the European Lisbon Council in 2000, has been repeated incessantly ever since. Yet the nation-state has unquestionably remained the primary focus of loyalty in Europe (Andrew, Crook \& Waller, 2000), a loyalty which is the cause of a recurrent frustration with the realities of Unionization. It's important to remember however that it took centuries to build nations, thus it should be expected the construction of political Europe is certain to be an extended processas well. However, as Dominique Schnapper argues, creating the conditions for the construction of a "European public space", would be a more helpful approach than the recurrent and overwhelming rhetoric on the topic of "European identity" (2002, p. 9). The latter will certainly result in claims for education as the location wherein the European citizen may be modeled. European Commissioner for Education and Culture, Viviane Reding, has betrayed the probability of this tendency by stating: "If we want to build a living Europe, with a soul, a destination and a world role (...) it is there, in the schools, the universities, the training centers, that Europe can grant itself a soul” (2000, p. 2).

Identity, heritage, soul - such terms are invoked to conjure the idea of a European citizenship. We don't intend to enter into discussions already begun (Bellamy \& Warleigh, 2001; Cederman, 2001; Eder \& Giesen, 2001; Schnapper, 2002) because we feel that such a debate results in an exaggeration of Europe which is unsustainable. As Dipesh Chakrabarty has said, this debate obscures the fact that Europe is "not the centre of the world, but only a small group of nations occupying a small region of the world that has attracted attention to itself during the last few centuries” (cf. Argyrou, 2001, p. 222). One of the more prominent positions 
in this dialogue emphasizes a postnational collective identity to "provide a social basis for transnational institutions" and account for what is "shared" by those contained within the space which those institutions govern (Giesen \& Eder, 2001). Gaspare Nevola even goes so far as to describe a "European patriotism of multinational citizenship" (2001, p. 343). Nevertheless, when one considers different theoretical and practical developments, it seems that the model of nation building remains central, and that terms such as multiple and variable geometry are simply evidence of an incapacity to outline a "new form" of citizenship. It is obvious that a dynamic of "inclusion" and "exclusion" must also be factored in, evinced by an increase in racial and social issues: "The institution of European citizenship is an attempt towards defining who is an insider and who is not" (Eder \& Giesen, 2001, p. 2). But there are more questions than answers, and the answers have already been suggested are not convincing to most Europeans.

\section{Education, Education, Education}

Historicism contents itself with establishing a causal connection between various moments in history. But no fact that is a cause is for that very reason historical. It became historical post-humously, as it were, through events that may be separated from it by thousands of years. A historian who takes this as his point of departure stops telling the sequence of events like the beads of a rosary. Instead, he grasps the constellation which his own era has formed with a definite earlier one. Thus he establishes conception of the present at the "time of the now" which is shot through with chips of Messianic time (Benjamin, 1968, p. 263).

Educational systems have been defined as a consequence of events in which they play a role in determining, and of which they are themselves a result. There is in addition a clear connection between comparative research and social and political processes of historical change. Benjamin's notion of Messianic time refers to the idea that human history is a nearly indetectable fraction of the totality of historical time, coinciding with the fact that the historical present is merely an abridgement of the entire history of humankind. Benjamin thus opens up another possibility for the comparative approach and the history of education.

The nineteenth century is often recognized as the period during which the concept of national identity was developed. The consolidation of culture within political boundaries was a process which necessitated the legitimization of a particular history or literature, not to mention the endowment of certain values with the status of collective ideals. This process has been described as the formation of a "civic religion", constitutive of a national "self-image" (Bourdieu, 1994). Concomitant with the development of national identity was the rise of mass schooling. The purpose of the educational institution expanded from having simply to do with instruction in academics, to the inculcation of what it meant to be citizen of a given nation-state. Thus education came to play a role in state building and political unification. National ideology would be challenged during the twentieth century by movements which 
sought to promote other criteria for identification, such as class or race, but at the beginning of the twenty-first century nationalism at the country level has remained as the dominant form of collective identity.

In the context of the nation-state, as a transmitter of national identity, education plays the role of linking the private citizen with the public polity. As the role of the nation has grown and transformed (particularly in terms of the development of the colony into post-colonial status), so has education expanded into a globally recognized institution. As the primary site for the promotion of modernity in terms of intellectual and technological progress, the school has served as the institution most responsible for the integration of the individual into the wider society. European Unionization however is an indicator of the fact that the dominant form of political organization, the nation-state, is open to challenge. Therefore, we are justified in wondering whether we are nearing a period in which the school as well, or at least its role, may be radically transformed. Whatever happens to citizenship in the context of the European Union, it seems clear that education will be subject to the same dynamics. References to a European "collective consciousness" lead to the assertion that this consciousness must be educated. In a certain way, it seems that nineteenth-century processes of identity building are being replicated nowadays in Europe. It is true that several authors try to explain the differences between these two processes. But, when it turns to education, we end-up with the same kind of expectations, and even the same kind of words, used more than a century ago: "education and training are not only the engines of growth and of economic innovation, but also the keys for creating a genuine European citizenship” (Reding, 2000, p. 1).

It seems that our thinking is "frozen" in a particular historical period, and that nothing else can even be imagined. It would be easy to present hundreds of works to expand this argument. But we will only use two recent texts, by Elie Barnavi and Lars-Erik Cederman. In the first case, a strong case is made to incorporate European identity in the collective consciousness of Europeans: "We have the formula for this (...). One need only draw from the arsenal of the nation states. This arsenal has a name: education” (2002, pp. 92-93). For Barnavi, promoting European identity means educating Europeans about being European, by showing them what unites them around a common history, values, mentalities, and lifestyles. Yet in a different perspective, Cederman also asserts that "more than anything else, public education serves a central function not just as a knowledge producer but also as a creator of citizens" (2001, p. 140).

It is interesting to analyze these claims, and to use them to understand the demands being put upon education, or better, the "European educational space". This space is occupied by two approaches towards the achievement of a common European educational system referred to before the pragmatic and identitarian approaches. The first consists of comparatively modest, logistical concerns such as mobility, recognition of diplomas and 
credentials, employability and the enhancement of quality. In the case of the latter, on the other hand, the focus is placed on what has been called the "European dimension of education", encompassing more sensitive issues such as curriculum content and teacher training. These two perspectives are combined, in several ways, in most EU policy orientation, which we will analyze in the next section of this chapter, dedicated to European educational policies. 


\section{TOWARDS A EUROPEAN EDUCATIONAL SPACE?}

The [European] Commission believes that no single Member State can accomplish all this alone. Our societies, like our economies, are now too interdependent for this to be realistic. While we must preserve the differences of structure and system which reflect the identities of the countries and regions of Europe, we must also recognise that our main objectives, and the results we all seek, are strikingly similar. We should build on those similarities to learn from each other, tho share our successes and failures, and to use education together to advance European citizens and European society into the new millennium (European Commission, The concrete future objectives of education systems, 2001, § 37).

Education has been one of the most contested arenas in Europe, not only due to its symbolic value in national imaginaries but also because of public resistance to a "common policy”. The results of the Eurobarometer ${ }^{5}$ reveal that a majority of European citizens believe that the formulation of educational policies should remain at the level of each Member State. The European Union put forward some measures in education and training, but simultaneously reiterated in their literature, namely in the Treaties, that the formation of educational policies should remain at the national level. The history of educational policies within the European Union is well-established (Hingel, 2001; Novoa, 2000, 2002). Results of opinion polls published by Eurobarometer determined that education should remain the primary concern of member states, thus inhibiting the integration of policies at the European level. It has been clear, however, for quite a while that there has been an ongoing effort to inscribe a "European dimension" into national educational policies. The attitude of the European Commission towards the integration of education systems within the Union has been described as a consistent effort to proceed “one step further” (Berggreen-Merkel, 1999, p. 2).

5 The Eurobarometer publishes results from various surveys and research instruments used to measure the "public opinion” on European issues (http://www.europe.eu.int/comm/public_opinion). 
This does not necessarily mean, however, that greater unification has in fact taken place in education. A number of studies have shown that there has not been a marked convergence at the institutional or policy levels, or in terms of the structure or practice of education and training (Green, Wolf \& Leney, 1999). Yet we cannot ignore the fact that since the middle of the 1980s, and increasingly in recent years, the programs and guidelines that have been implemented at the European level reflect a consensus of thought about education. Our argument is that Europe functions as a regulatory ideal, that tends to influence, if not organize, national policies. It is obvious that "homogenization" will not occur, and in fact talk of the "diversity" of national educational systems is almost tautological. Nevertheless, the tendency towards defining common goals, similar strategies - and thus the formulation of identical policies - can be expected to recur. The complexity of this debate requires the adoption of new theoretical tools and approaches. References to traditional distinctions and dichotomies will not enable new understandings. An arithmetical conception of power - less power at the national level meaning more power at the European level, and vice-versa - is totally inaccurate. Indeed, one could just as well consider the European Union to be a political form which strengthens the nation-state, acknowledging that among its institutions and the levels of decision-making, it is the Member States and their representatives who are most powerful (Peterson, 2001). It is also important to remember that in most national states the local and regional authorities hold important responsibilities for decisions on education. Thus dualistic and simplistic analyses will not enable us to understand the actual dynamics of what is taking place.

An important document issued in March 2001, by the head of the educational policy unit in Brussels does, however, provide us with a clearer picture:

Since the very beginning of European cooperation in the field of education, Ministers of Education have underlined the diversity of their systems of education. The very reason why they met was in fact that their systems were diverse. Any mentioning of common denominators was considered of lesser importance and mainly used in national debates. The Lisbon conclusions break with this by asking the Ministers to concentrate their reflection on what is common. [ ] the Lisbon conclusions implicitly give the Union the mandate to develop a common interest approach in education going beyond national diversities as can already be seen in the demand to Ministers of Education to debate common objectives of educational systems. This mandate will lead to an increase in the European dimension of national educational policies (Hingel, 2001, pp. 15 \& 19).

The intent to legitimize a "common approach" to educational policy is clear. Though the statement that most educational matters are still decided at the national level is undeniable the word "still" must be emphasized. This is why the controversy taking place at the end of the 1990s with regard to the so-called "European educational area” seems definitively closed. Going only as far back as 1999, however, it is still possible to find arguments such as the one presented by Berggreen-Merkel: “Acknowledging the many actions in the field of education 
and training (...) justifies the Commission's assertion that by law and by facts the European Union is aiming for already building on a common European educational area. However (...) one should refrain from using this term. (...) It would be easier to talk about a European area of educational cooperation and mobility” (1999, p. 6). The jurisdictional, cautious nature of this rhetoric seems naive in light of recent political developments. Only two years later, the head of the EU education policy unit has not hesitated in reframing this discussion, and moving one step further: "What is presently happening in co-operation in the field of education tells us, that not only is a European Space of Education in its making, common principles of education are being agreed upon between member States, leading logically to a European Model of Education" (Hingel, 2001, p. 4).

To develop an understanding of this process, which we interpret as a shift in the construction of EU policy guidelines, is the goal of this chapter. We will focus on the last decade (1992-2002), and argue that the year 2000, particularly during the period of the Portuguese presidency of the European Union, marks a turning point. After several years of working on the possibilities opened up by the Maastricht Treaty, an acceleration and deepening of educational policy at the European level took place. In order to address this decade-long process we will use a metaphor describing different states of matter, that allow us to describe not only the "proprieties" of the matter, but also to understand different ways of occupying "space".

\section{Maastricht (1992): A first turning point}

The first phase of European cooperation in the field of education can be called the liquid state of politics. The association between schooling and identity formation, not to mention restrictions enforced through various treaties, have limited the potential for policy application on the part of the European Commission in education. The result has been the development of what we may refer to as a "logic of programmes" - i.e. something that is not inscribed in the routine of schools or regular practice of education policies, but rather is formulated as voluntary or temporary agreements. The outcome has been programmes that are described as more successful, particularly with regard to mobility and exchanges. Nevertheless, one should not ignore three other tendencies, which have been present since the initial attempts at cooperation in the educational field.

To begin with, a broad interpretation of “vocational training” has allowed the European Commission to intervene in many educational areas, particularly in higher education. This was done through the application of certain provisions related to the "labour market", transforming the liquidity of politics into the solidity of regulation, in terms of an over-determination of education by the economic context of the job market, and the "necessity" of creating a "qualified” work force. Secondly, the construction of educational statistics, taking place for the 
first time at the European level, created the obligation for countries to organize data, based on similar criteria. ${ }^{6}$ This trend towards the homogenization of information, justified by the claim that was the only possible way to compare European educational systems, also led to the solidification of politics. In fact, the invention of "comparable indicators" is as much a way of constructing reality as it is of describing it. A final factor has been the constant, often subliminal, presence of claims concerning the introduction of a European dimension into the curriculum. We refer to this inclination as a vaporization of politics, because it transforms liquidity into a much vaguer, boundless state. This usually consists of references to European heritage and values. In fact, however, as Lars-Erik Cederman (2001) has noted, most of these attempts have fallen on deaf ears.

It is clear that the first phase of European politics was characterized by liquidity (principles of mobility, "voluntary" exchange and communication), though it is possible to detect tendencies towards solidification and vaporization as well. We will argue that, in various ways, these three states of matter are always present inside the European Union. An important turning point took place in 1992-1993, with the approval of the Maastricht Treaty and the discussion surrounding it. Throughout the 1990s a large body of literature was produced, describing the significance of Maastricht: "By introducing Art. 126 and 127 into the Treaty of Rome, the Treaty of Maastricht had taken into account the fact that in spite of the lack of explicit Community powers to deal with education as a whole, a common educational policy had gradually been established” (Berggreen-Merkel, 1999, p. 1). It is not worth returning to these arguments, so well known by those familiar with European studies (Müller-Solger, 1999). Most of the documents issued after 1992-1993 begin by asserting the need to develop quality education, a catchphrase which served to legitimize European initiatives in this area. This phase is characterized by what we refer to as the vaporous state of politics. The metaphor is used to address the occurrence of strong rhetoric, particularly with reference to the "society of the future", but also to certain concepts such as "quality education” or "lifelong learning”. Occupying all available space, as only gas or vapor may do, they de-legitimize alternative ways of thinking.

${ }^{6}$ See the history of Eurydice, the information network on education in Europe (http://www.eurydice.org). 
With reference to the period under discussion (1993-2000), it is possible to distinguish three different approaches, all contributing to a vaporization of European educational policies. First, there is the recurrent discourse concerning the European dimension of education. This is condensed in the green paper of the same title, issued in 1993. One imagines a "past”, which legitimizes current European institutions, yet at the same time invents a "future", which supports contemporary political decisions. Important groups have been mobilized to fulfill this goal, particularly in the fields of history and literature, yet one cannot avoid a sense of irresolution at the level of identity, as citizens become only fragments upon which past and future are inscribed. Second, the emphasis on lifelong learning betrays a desire to find a single solution for a variety of problems. Lifelong learning is not only invoked with reference to education and schooling, but also to the problems of unemployment and preparation for the job market. One may observe how this concept was re-articulated and, to a certain degree, reinvented to address social and economic problems within the European Union. The year 1996 was named as the "European Year of Lifelong Learning", and since then the term has continued to permeate European policy as a panacea: "As such, lifelong learning plays a central role in promoting social inclusion, in enhancing European competitiveness and in combatting unemployment” (Reding, 2000a, p. 4). Finally, we may refer to a collection of papers and reports, issued and published for the purpose of identifying important issues in the educational field. These documents develop a space for "future politics" with an appealing language: Teaching and learning: Towards the learning society (1995), Accomplishing Europe through Education and Training (1997), Towards a Europe of Knowledge (1997), Learning for Active Citizenship (1998), etc. Though they have had no immediate political consequences, their rhetoric imposes a way of considering education, delineating vital orientations. They establish a future consisting of that which is "personally or socially desirable, rather than what is objectively likely” (Bennet, 2001, p. 194), even as they produce new memories to fill the space of history they have rewritten. These documents are thus part of a political construction which imposes as natural what is in fact particular.

It is important to keep in mind, however, that referring to something metaphorically as vaporous, with the attendant associations of intangibility, does not mean that these policies are insubstantial. The fact that these ways of thinking occupied all available space impeded the emergence of alternative discourses. It is important to recognize how certain ways of discussing come to predominate, even as they de-legitimize other approaches as "old-fashioned" or "unrealistic", consigning them to the dust-bin of "criticism”, "unrealism” or "outdated-ness". ${ }^{7}$ Meanwhile, some polices during this same period were solidified after entering into contact with certain social or economic realities. This was clearly the case with

${ }^{7}$ This process may be observed, for example, in the evaluation by the European Commission, and/or by experts nominated by the European Commission, of research proposals in the field of education. 
lifelong learning, once it became instrumental in solving the problem of unemployment and addressing the crisis of the so-called "European social model”. This was also the case with the "prospective discourse" as read against the background of the "new technological era”, leading to important changes in the institution of schooling, as well as conceptions of the learning process. $^{8}$

\section{Lisbon (2000): A Second Turning Point}

${ }^{8}$ It is s interesting to note the popularity of the concept of lifelong learning in recent EU documents. An example can be found in the Bulletin EU, with reference to strategies identified in order to implement the Commission communication Making a European area of lifelong learning a reality: "working in partnerships across the learning spectrum, understand demand for learning, facilitating access to learning opportunities, providing adequate resources, creating a learning culture and maximizing the quality of the learning experience itself $\left(\mathrm{n}^{\circ} 11,2001\right)$ (emphasis added). 
The adoption in 1999 of a "rolling agenda" by the Education Council signaled an increasing integration of European educational policies. The following year in Lisbon two important decisions were made: one, to move towards a knowledge-based economy as the "way forward" towards Unionization, and two, the adoption of an open-method of co-ordination, "coupled with a stronger guiding and coordinating role for the European Council to ensure more coherent strategic direction and effective monitoring of progress" (2000, § 7). The means to achieve a "knowledge society" was described in terms of an "investment in people", by placing education at the forefront of European initiatives. Therefore it is not surprising that the European Council requested that the Education Council "undertake a general reflection on the concrete future objectives of education systems, focusing on common concerns and priorities while respecting national diversity” (2000, § 27). Extending upon our metaphor, we can mark this as the point of transition to a solid state of politics. This solidity is confirmed by systematic use of benchmarking as a strategy to implement the open-method of coordination, creating instruments that will allow for monitoring and evaluation of progress achieved.

Keeping in mind the association between structure and solidity, it is interesting to note that at the time of the Barcelona European Council (March 2002), the Spanish Minister of Education stated that education should be considered as the "fourth pillar" of the European Union. ${ }^{9}$ In the last two years (2000-2002) important changes have taken place, reflecting an intention to establish common objectives, as well as common indicators to monitor and assess European educational systems. As noted by Dermot Hodson and Imelda Maher, the open method of co-ordination "is being applied in new areas, such as pension reform and education policy" (2001, p. 725). With this in mind it is worth underlining the significance of the Memorandum on Lifelong Learning (2000) and the European Report on Quality of School Education (2000).

${ }^{9}$ Legally the European Union is organized in terms of three pillars: the European Communities, Common and Foreign Security Policy and Cooperation in Justice and Home Affairs (Dinan, 1999; Moussis, 1997). "Education and Culture" are included in the first pillar, thus this call for education to stand alone as its own pillar is to make the point that it is to vital to be subsumed under some other category. 
As for the former, lifelong learning is broadly defined as "all purposeful learning activity undertaken with the aim of improving knowledge, skills and competence, whether formal - in pre-school, school, higher education, adult education, vocational training - or informal, in work and leisure environments” (Reding, 2000a, p. 4). Furthermore, lifelong learning is considered to be a key factor in creating an "active employment policy", as well as being the main strategy for enhancing employability and to "promote quality in employment" (“Annexes to the European Council Conclusions", Bulletin EU, $\mathrm{n}^{\circ} 12,2000$ ). As for the development of quality education, this entitled the European Commission to, for the first time, set up a series of "indicators", selected by a "working committee of experts", whose aims were described by Anders Hingel in Le Magazine, where he wrote: "Of course, not all countries are ready to implement the concept of benchmarks. But this report deserves credit for confronting education ministers with the challenges brought to light by the results of the indicators. In what we might call a logic of emulation, they are now endeavoring to learn what the others are doing better" (2001, p. 5). Thus one may clearly understand the central role which the European Commission is being asked to play in the regulation of educational policies. The political rhetoric is characterized by repeated references to principles such as "diversity", "full responsibility of member states", and so on. However these terms are now coupled with references to "common objectives", "reinforced co-operation", and "mutual accountability". This is the new manner of formulating educational policies, at the national and European levels, which has been in the process of being defined in recent years.

The report from the Commission, The Concrete Objectives of the Education Systems (2001), expresses this shift. Throughout the document we are presented with a series of "concerns", "concrete objectives", "methods for policy implementation" and "evaluation indicators". In March 2001, the Stockholm European Council confirmed its "top priority to make the Union the most competitive and dynamic knowledge-based economy in the world", an intent inclusive of an emphasis on education policies and the principle of lifelong learning. This same aim was present one year later when the Barcelona European Council agreed upon a program to be achieved by 2010, which would focus on education and training systems (Work Programme for 2010). Henceforth it will be impossible to ignore the existence of a European educational space, consisting of two tendencies: one, education policies increasingly formulated at the European level, two, the increasing influence of these developments on national policies. This is not a process which will be accomplished through legislation or compulsion, but rather through emulation, cooperation and participation. It is difficult to imagine a Member State opting out of this game of “freely adhering” to shared guidelines. The outcome of this issuance of guidelines and documents, coming from multiple EU institutions, is illustrated in terms of current political trends in the educational field, reflected in the Work Programme for 2010. This, therefore, is the document we will focus on in the next section. 


\title{
III. THE WORK PROGRAMME FOR 2010: A NEW TEMPO FOR EUROPEAN EDUCATIONAL POLICIES
}

\begin{abstract}
The Council and the Commission request that an Education and Training Area now be explicitly recognised as a key priority domain in the Lisbon strategy. (...) making the European Union the leading knowledge-based economy in the world will only be possible with the crucial contribution from education and training as factors of economic growth, innovation, sustainable employability and social cohesion (Council of the European Union, Detailed work programme on the follow-up of the objectives of education and training systems in Europe, 2002, p. 10).
\end{abstract}

The Work Programme for 2010 clearly establishes a new tempo for European educational policies. Elaborated at the beginning of the year 2002, it builds on events and initiatives that have taken place since the Lisbon European Council, showing "that the development of education and training systems in a lifelong learning and in a worldwide perspective has increasingly been acknowledged as a crucial factor for the future of Europe in the knowledge era" (2002, p. 9). ${ }^{10}$ The primary purpose of the program is to organize EU educational standards into a "single comprehensive strategy", consisting of two types of activity: work on common challenges, and efforts to utilize the potential of transnational activities in education and training (2002, p. 13). The document defines three strategic objectives, broken down into thirteen related objectives and forty-three key issues. ${ }^{11}$ Implementing the new "open method of coordination", these issues and objectives are said to be based upon "the identification of shared concerns and objectives, the spreading of good practice and the measurement of progress through agreed instruments, comparing achievements both between European countries and with the rest of the world” ( 2002, p. 6). Without going too much into detail, our analysis of this document will focus on the content of the form and the form of the content - playing on the title of the well-known book by Hayden White (1987). We will first address questions of "method" and "structure", explaining how they are part of the content of the policies adopted. We will then give attention to the three stated strategic objectives, in order to understand how they imply new conceptions of

10 Throughout this section we will be quoting the document Detailed work programme on the follow-up of the objectives of education and training systems in Europe, which we will refer to as Work Programme for 2010, as it is cited in the conclusions of the European Council. Those familiar with EU materials know that several, slightly different versions of the same document typically exist. The reason for this has to do with the complexity of European institutions and the fact that the same document must be approved by different bodies. In this chapter we will be referring to document 6365/02 - EDUC 27, approved in 2002 by the Education Council (February 14) and by the Barcelona European Council (March 15-16).

11 On page 12 the document refers to "forty-two" key issues, which is actually incorrect. The mistake itself is irrelevant, except in that it confirms our earlier contention with regard to the "provisional nature" of EU documents. 
education, as well as a change in the inter- and intra-relationships of European states.

\section{The content of the form:}

\section{A strategy, a method, a structure}

The building of a "single comprehensive strategy" implies the obligation to clarify both a method and a structure for educational policies. The Work Programme for 2010 is quite transparent on these issues, emphasizing the four verbs quoted above: identify, spread, measure and compare. To identify means to agree on shared objectives and guidelines for educational policies, and to spread refers to the diffusion and transfer of most successful practices from one country to another. To measure is to establish precise benchmarks and to evaluate the performance of each educational system, and to compare means to organize a way of assessing the progress made by each country. It is pointless to restate the overt intention that all of these convergence policies be adopted on a voluntary basis by each member state, a contention reflected in the document by abundant references to "agreed instruments", "voluntary participation”, "partnerships” and "decentralized approaches”. The goal of this process is described as "to help Member States to develop their own policies progressively" (2002, p. 12), which we translate as: "to help Member States to develop their own policies progressively, in accordance with the objectives defined at the European level”.

The method is to utilize tools "such as indicators and benchmarks as well as comparing best practice, periodic monitoring, evaluation and peer review etc. organized as mutual learning processes" (2002, p. 12). The structure of the document underlines this tendency presenting, after the description of each of the thirteen objectives, the "indicators for measuring progress" and the themes of "exchanging experience", "good practice" and "peer review". The new tempo is determined by a will to "solidify" European educational policies, creating the instruments to monitor, evaluate and compare the progress achieved. The four key verbs identify, spread, measure and compare - serve to construct a "way of thinking" in which the form defines the content of educational policies. This same dynamic can be seen in the table presented at the end of the Work Programme for 2010 - "Model to be used in the follow-up of quantitative indicators to support the implementation of the objectives using the open method of coordination" - shown below (a footnote explains that all decisions will be made by consensus and on a voluntary basis, even if "this process of implementation will require the availability of national statistical data according to the indicators chosen”):

\begin{tabular}{|l|c|c|c|c|c|c|c|}
\hline & \multicolumn{2}{|l|}{ Present Levels } & \multicolumn{2}{l|}{ Progress } & \multicolumn{2}{|c|}{$\begin{array}{c}\text { Benchmarks/ } \\
\text { Reference Criteria }\end{array}$} \\
\hline & $\begin{array}{c}\text { Average } \\
\text { (EU) }\end{array}$ & $\begin{array}{c}\text { Average of 3 best } \\
\text { perfor-ming } \\
\text { (EU) }\end{array}$ & $\begin{array}{c}\text { USA and } \\
\text { Japan }\end{array}$ & 2004 & 2010 & $\begin{array}{c}\text { for } \\
2004\end{array}$ & $\begin{array}{c}\text { for } \\
2010\end{array}$ \\
\hline Indicator & & & & & & & \\
\hline Indicator & & & & & & & \\
\hline Indicator & & & & & & & \\
\hline
\end{tabular}


It is useful to underline three ideas which contradict the strong rhetoric contained in the statements put forward by EU officials. First, the claim that the purpose of the exercise is "to learn from one another, not to single out the good pupils from the bad" (Le Magazine, $\mathrm{n}^{\circ} 14$, 2001, p. 5). In fact, the intention is to organize a league table for nations. The comparison made is between the "average (EU)" and the "average of three best performing (EU)", versus the "rest of the world". Curiously enough, the entire "rest of the world" is represented only by the United States and Japan. A second idea is related to a policy, defined through "benchmarks", creating an educational discourse that includes indicators, outcomes, data and knowledge, which functions as a regulating rule, obliging everyone to refer back to it. Cohesion and configuration of policy is not achieved through sanctions, but through a much more sophisticated approach. Voluntary participation by each nation-state, without any compulsory obligation, serves to legitimize these arguments. It is difficult to imagine how a national state could stand outside of this "playing field". Finally, let us mention the importance of the harmonization of statistical data. This process is not simply a matter of collecting and organizing data, rather it is a process that constructs educational realities as much as it describes them. Through the arrangement of categories and classifications, a definition of the "best system" is proposed, suggesting the policies necessary to proceed in this direction. An analogy can be established according to arguments raised by Peter Miller, with reference to "calculative practices": "Management accountings seeks to affect the conduct of individuals in such a way that they act freely, yet in accordance with specified economic norms” (2001, p. 380). In fact, the idea of building “comparable indicators” is best understood as a powerful way of formulating educational policies.

\section{"We are all comparativists now"}

Despite increased recognition of the multiple ways in which communities are composed and imagined, the nation-state as an approach to political and social organization remains predominant (Anderson, 1991). Yet at the same time is necessary to acknowledge processes of globalization and reorganization of the world through interdependencies and political agreements, as in the case of the European Union. The formulation of policy is increasingly subject to pressures which challenge the legitimacy of democratic governments, and it in this context that comparison has emerged as a method to construct and interpret data. The key term surrounding this process is "benchmarks", by which one may measure "outcomes" and thus establish "standards". These terms are part of a discourse, established by experts devising the concepts, methodologies and tools of comparison. The production of these terms is contingent upon the politics of "mutual accountability", referring to a process by which schools share and participate in a process of comparison. The notion of "mutuality" implies a horizontality, but the result is in fact a vertical hierarchy, with a ranking established upon the basis of standards which are assumed to be "natural" or "evident".

Thus comparison can be understood as a mechanism to justify EU interference in local 
educational issues. The logic of comparison produces a vocabulary consisting of positive terms such as "exchange”, “joint reflection” and "agreement”. Meanwhile, fear of uniformity or homogeneity is negated by an emphasis on "independent" identification of "best practices" within this context of comparison. Reference points are established through comparable criteria which provides the appearance of transferability. What is presented as a strategy to improve education is however in actuality a mode of governance. Democracy is circumvented as policy formation is removed from the purview of politicians and citizens, and falls under the control of groups conducting research and organizing the data culled from comparison.

\section{The form of the content: \\ Quality, access, openness}

The Work Programme for 2010 returns systematically to the same issues, in a narrative construction that is intentionally circular and redundant. Two terms appear repeatedly, defined and redefined according to context - the first is "quality" and the second is "lifelong learning". These concepts are useful in addressing the form of the content, found throughout the document: on the one hand, they define a strong tendency towards mechanisms of evaluation, leading to rankings and classifications that consecrate as "inevitable" a particular way of conceiving education and schooling; on the other hand, they introduce a new approach to educational matters, at both the personal and the social level, stressing the responsibility of each individual to constantly update his or her skills so as to enhance and maintain their own employability. With this in mind, we will characterize the three strategic objectives of the Work Programme for 2010, examining critically how they are defined and presented.

\section{“Improved Quality”:}

Andante com moto (tempo misurato)

"Improving quality and effectiveness", is the first strategic objective of the Work Programme for 2010. Besides the usual references to teacher education, new technologies, scientific and technical studies, as well as the best use of resources, the document focuses on key competencies for the so-called "knowledge society". The identification of these competencies is not very different from the "attainment indicators" chosen in 2000 to evaluate the "quality of school education" (cf. European Report on the Quality of School Education, 2000, p. 7). “Mathematics”, “Reading”, “Science”, and "Foreign Languages” are accompanied by "Information and communication technologies", and by "Learning to learn". The former reference to "Civics" is now replaced by "Social skills" and "Entrepreneurship". ${ }^{12}$ It is no

${ }^{12}$ Indicators included in the Quality Report on the Quality of School Education: Mathematics; Reading; Science; Information and communication technologies; Foreign languages; Learning to learn; Civics (2000, p. 7). Key competencies identified in the Work Programme for 2010: Numeracy and literacy (foundational skills); Basic competencies in mathematics, science and technology; Foreign 
surprise that the "key competencies" are organized into three groups - scientific, communicational and technological. The exclusion of the humanities, in the broader sense of the term, is accompanied by a psycho-sociological and entrepreneurial discourse. This emphasis is very clear with reference to the three "key competencies": "Learning to learn" is an old pedagogical concept that is redefined by constructivism, but also by the business world, in terms of lifelong learning; "Social skills" contains a perspective that relates to personal relations and networks, as well as to principles of self-responsibility and citizenship; and finally, "Entrepreneurship” signals attention to initiative, management and risk. ${ }^{13}$

languages; ICT skills and use of technology; Learning to learn; Social skills; Entrepreneurship; General culture (2002, p. 18).

13 This idea is so important in the framework of the Work Programme for 2010 that it comes back again in the third strategic objective: "Education and training should provide an understanding of the value of enterprise, as well as models of successful entrepreneurship, of the value of risk-taking and of the need for everyone to have a sense of initiative” (2002, p. 36). 
The intent to ensure and to monitor quality education leads, not only to a call for more investment and a reinforcement of public-private partnerships, but also - and this is the point we would like to stress - to the evaluation of progress and achievement through comparable benchmarks and indicators. ${ }^{14}$ Issues of quality, determined through the politics of comparison, are underpinned by an expert-discourse that is developed on a global scale, but that is reinforced at the European level by an effort to integrate national policies. One of the main objectives of this policy is to place "less emphasis on the control of input" and "greater emphasis on the control of output". The practices of audit and accountability seek "to provide policy makers with reference points" by rendering visible their "failures" and "successes" in terms of indicators and standards that have been "commonly" defined and "freely" accepted. In this sense, they are governing principles that construct an educational policy lying in specific forms of knowledge and expertise. The intention is "to create an open and positive climate for dialogue", and "to provide a strong basis to learn from one another". We need to understand this "learning from one another" as a process of constructing a way of thinking and acting in the educational field. We can say that "the challenge of data and comparability" (to quote the words of the European Report of the Quality of School Education) establishes a policy without specifically formulating it. And this is the most effective way to change educational systems. At a constant and synchronized speed, slowly but steadily, in tempo misurato, a European educational policy is on the march.

\section{"Facilitation of universal access": \\ Allegro ma non troppo (tempo a piacere)}

The formulation of the second strategic objective of the Work Programme for 2010 "Facilitating the access of all" - intentionally emphasizes issues related to lifelong learning. It articulates the conventional discourse concerning lifelong learning in European institutions by, on the one hand, redefining "employment" as a learning problem that should be solved by each individual and, on the other hand, creating the illusion that the "crisis of schooling" will be resolved if individuals simply continue to expose themselves to education and training throughout their entire lifetime. The uses and abuses of this concept must be understood within the overall framework of providing a "magic solution" for some of the deeper concerns of the European public. Unemployment has been portrayed, particularly by the media, as one of the most important European problems. Therefore, it is no surprise that the European Union places it at the heart of its agenda to eliminate "social exclusion". It is essential to understand the social relevance of these issues as European states are forced to deal with persistently high levels of unemployment and low rates of job creation. In all of the European guidelines for improving employability, the emphasis is placed on education and training for young people,

14 "This goes for public spending in human resources, spending in private enterprises and investment by each individual” (Work Programme for 2010, 2002, p. 26). 
as well as on lifelong learning. In fact, the concept of employability was recently reinvented as a way to link employment with education, or to interpret unemployment as a problem of "uneducated" people. The mobilization of this concept in political discourse entailed its transition from the social or economic sphere to the individual sphere. Therefore, it is easy to understand the decision to place lifelong learning at the core of European educational policies, from the "pre-school age to that of post-retirement, including the entire spectrum of formal, non-formal and informal learning” (Education and lifelong learning - Council Resolution, 30 May 2002, p. 6).

The implication of this emphasis on lifelong learning is that responsibility for resolving the crisis of the Welfare State (and/or the European social model) shifts to citizens who are invited to become responsible for "constantly updating their knowledge" in order to enhance employability and consolidate the process of Unionization. This negation of responsibility at the political level entails a new relationship between the individual, the collective, and the notion of work. This relationship will now be mediated by a "ceaseless" process of "training and retraining, skilling and reskilling, enhancement of credentials and preparation for life of incessant job seeking: life is to become a continuous economic capitalization of the self' (Rose, 1999, p. 161). Consequently, social crisis phenomena such as structural unemployment can be shifted as a burden of risk onto the shoulders of individuals relieving the state of accountability: "The idea of the labour market (...) is replaced by the idea of self-employment: Set up your own business! Your business is your talent! Live and work like an artist! Be a net-worker!” (Beck, 2001, p. 268). Active citizenship, entrepreneurial culture and lifelong learning are part of a process of reconfiguring the self. To understand this it is essential to recognize that economics involves multiple overlapping discourses, based in social, economic and political dimensions. In fact, as Peter Wagner (2001) explains, it would be misleading to discuss the notion of the "entrepreneurial self" only as an economic injunction. Relying on this reformulation, European educational policies are creating new conceptions of the "reasonable" and "responsible" lifelong-learner and, at the same time, constructing an ideology that blames individuals who are unable to take care of their "own life", that is, their "own education". The “Open learning environment”, "Making learning more attractive”, and "Supporting active citizenship, equal opportunities and social cohesion", are goals to be achieved in the context of this objective, in a process played in tempo a piacere - at a high rate of speed... ma non troppo, when encountering issues of employability.

"Opening-up to the wider world":

Adagio cantabile (tempo rubato)

The third strategic objective - "Opening-up education and training systems to the wider world" - takes on issues of strengthening links between education and the workplace, improving foreign language learning, as well as increasing mobility and exchange. It is defined 
with reference to broad statements (on "cooperation”, “openness”, "sense of initiative”, etc.), but also in terms of precise measures of validation or recognition, quality assurance and accreditation. The goal is to create an open "European area for education" and to promote the "European dimension of teaching and training". Mobility within the European space is described as not simply movement, but rather as a process which develops awareness of what it means to be a citizen of Europe (Work Programme for 2010, 2002, p. 40). The idea of "experiencing Europe" is concurrent with programs of mobility and the project of reinforcing European citizenship. As we have already discussed, these issues are quite complex in the European context: on the one hand, the restructuring of memories is a cultural practice, "that forges narratives to instantiate visions of the citizen, the nation, and the new intra-national state of the European Union"; on the other hand, "old images of nation and self are dissociated from the new memories as people re-imagine themselves with a new collective narrative that relates to political projects bound to cultural identities” (Popkewitz, Lindblad \& Strandberg, 1999, pp. 52-53). The notion of citizenship is being transferred from the political and social arena to the individual sphere, simultaneously opening up new spaces of affiliation and identity. This is why the documents issued from Brussels combine an attempt to replicate a traditional sense of "nationhood" at the European level, with hybrid discourses permeated by expressions such as "diverse and overlapping values and identities", "variable geometry", "complexity and fluidity”, “multiple identities”, "flexible citizenship”, and so on.

One should realize that, in this instance, the politics of identity are formulated in terms of qualification and disqualification, leading to the formation of "new educated subjects", to populate the "knowledge society". Such a policy in effect exiles all those not endowed with requisite attributes, as well as those simply unable to acquire them. Once again, the concept of mobility is central, because not only does it contain an imaginary of historical journeys and cultural experience, but it also suggests a sense of freedom and openness towards the future. Perhaps "we are witnessing the revenge of nomadism over the principle of territoriality and settlement" (Bauman, 2000, p. 13), but we cannot ignore that "certain travellers are materially privileged, others oppressed” (Clifford, 1997, p. 35). As Ginette Verstraete (2001) argues, the contemporary realignment of European borders, discursively supported by the call for an abstract "right to mobility", produces at once new forms, as well as new impediments, to the notion of mobility. Even if the "knowledge society" is populated by "mobile people" (Cresswell, 2001), one needs to recognize that little scholarship has been done towards comprehending what might be called the journeys of European integration. And - what is still more relevant - almost no attempt has been made to understand that "the region called Europe has been constantly remade, and traversed, by influences beyond its borders” (Clifford, 1997, p. 3). The Work Programme for 2010 seeks to attract "students, academics and researchers from other world regions", expecting that European educational institutions will be "recognised world-wide as centres of excellence" (2002, pp. 40 \& 43). This objective is formulated against a background in which the United States of America is regarded as the primary competitor in the educational market. Again, the experience of Europe is inseparable 
from the "others" that live inside and outside European borders, from individual and collective itineraries, from contact-zones and networks where identities are constructed and reconstructed. But, with regard to educational policies, the piece is being played very slowly, and often in a lyrical style - even if, here and there, some decisions seem to disregard the strict value of the established tempo.

What music is being played in the European educational space? By analysing the Work Programme for 2010 it is possible to discern two themes recurring throughout the document. The first has to do with a systematic reference to the "new knowledge-based economy" and to principles of competitiveness and entrepreneurship. As stressed by Willy Wielemans, education is regarded as one of the main instruments "in the struggle against unemployment and in consequence must be better adapted to the requirements of the labour market (which again points to the dominance of the economic sub-system)" (2000, p. 31). The second is the frequent use of psychological concepts, applied to educational situations, which have the effect of reorienting pedagogical methods. This turn becomes quite obvious if we consider different uses of the concept of "learning" throughout the document: "learner-centred approaches" (p. 20), “making learning more attractive” (p. 30), “a culture of learning” (p. 30), "motivation of learners” (p. 32), “learning organisations” (p. 34), "learning at the work place” (p. 34), "flexible learning times to learners" (p. 29), and most importantly "learning to learn” (p. 18). The combination of these influences situates lifelong learning as central in our understanding of education. It is a way of making education relevant to economics, in terms of "sustainable employability". This serves the function of explaining to the individual citizen his or her responsibility to perpetuate their own learning. As Zygmunt Bauman remarks, each successive "project" that is undertaken must be seen through and fulfilled to the best of one's ability, solely in order to demonstrate ones "capacity of fulfilling projects", and to secure his or her employability when it comes to the allocation and appropriation of the next batch of projects: "A merry-go-round comes to mind rather than marathon running; a life as a string of rounds, a sequence of new starts, often in unconnected places and unrelated surroundings. Keeping fit for the next, yet unknown round, whatever it may be, is the main achievement, revocable as the rest” (cf. Bauman \& Tester, 2001, p. 89).

No doubt. The processes that we have just described are not specific to the European context. On the contrary. They are part of broader developments, that have been popularized by the imperfect concept of "globalization". But, inside the European Union, they are strengthened by a historic project that tends to integrate national states into a political union. And this fact gives them a new status, builds on new political possibilities. This is the main reason why this "unidentified political object" known as the European Union is a such an interesting object of study, both for comparative politics and for the socio-historical analysis of 
educational policies. 


\title{
CODETTA: NEW WAYS OF LOOKING TO THE “EUROPEAN EDUCATIONAL SPACE”
}

\begin{abstract}
The "politicization" of initiatives during the last few years in the field of education of injecting, "from the top", an acceleration and deepening of European co-operation might have been an answer to the more slow and more conservative development of Ministries and National education authorities (Hingel, 2001, pp. 18-19).
\end{abstract}

The words of Anders Hingel, head of the education policy unit at the European Commission, are worth remarking on for two important reasons. First, they construct an idea of "Europeanization", based on a logic of mutual accountability, as developed through an evaluation of, or comparison between, national systems of education, using a series of indicators, outcomes, benchmarks and guidelines. Despite their practical differences in terms of procedure, these concepts are generated as part of the same "discursive formation". Second, they break down resistance and inertia at the level of national authorities by defining "politicization" as a reinforcement of decisions "from the top", that is, directly by Heads of State. Thus the "educational space" is considered as a field of expertise where the main objective is to reach obvious and consensual "outcomes". It is worth to address three important issues that influence educational debates in the European Union.

First, the increasing "mediatization” of politics, well explained by G. Mazzoleni in terms of the metaphor of gravity: "Yesterday everything circled around the parties, today everything circles around, and in the space, of the media” (1995, p. 308). This is not to suggest that it floats in a symbolic ether, but rather that the space of politics has been reoriented towards greater visibility in "the public eye" (Schudson, 2002, p. 251). Second, in the context of European politics, this process is accompanied by the increasingly recurrent auditing and estimating of public opinion. These practices, based on the model of consumerism, give rise to forms of "democratic authoritarianism". This term is invoked by Ulrich Beck, when he points out that the "death of the nation-state" has been greatly exaggerated: "The nation-state is getting even more powerful in the dimensions of control, through information technology, in its regulation and audit of all kinds of areas, and through its power to make alliances with movements (religious, economic, international, regional) which don't relate to the democratic counter-power structure in modern societies like parliament and unions, and which even directly own the media, and so play a key role in forming and mobilizing popular opinion" (cf. Boyne, 2001, pp. 49-50). Finally, it is important to understand how these two processes are reinforced by a policy based on "the authority of the experts" and on the "recondite knowledge they are trusted to possess” (Bauman, 2001a, p. 25). This refers back to John Peterson's observation concerning the practice of removing issues to the "expert level" as a means of depoliticizing them (2001, p. 309). 
The conjunction of these different processes results in the formation of networks, where policy is determined (Leonard, 2002, p. 139). There is a tendency to consider the "European educational space" as a field of expertise, in which the main objective is to achieve consensus. Such a perspective is antithetical to the actual practice of education, and educational policies. For this reason it is vital to define the "public sphere", in the sense described by Jürgen Habermas (2001), as a place providing the possibility for participation in political discussion and decision-making. While we do not deny the necessary role played by the media, networks and experts, their relevancy must not exceed that of democratic practice. Furthermore, as we have argued above, the division between "Europe" and "nation-state" is the inaccurate result of linear or dichotomous accounts of European affairs. We require a more sophisticated perspective, based upon comparative approaches, inspired by theoretical frameworks rather than expert discourses. This is the only way of creating new zones and ways of looking, so as to overcome the "silences" and deconstruct that which seems natural or evident. This condition will fulfill our will to understand.

\section{The condition of comparative research}

As stated earlier, comparability has come to serve as a "mode of governance" within contemporary European debates. It is not significant in terms of any insights obtained, but rather only in terms of a process of "perpetual comparison", based on indicators, measures, standards and benchmarks. With this in mind, we argue that comparative approaches must be theorized and historicized so as to avoid a circulation of ideas lacking social roots or structural locations - contributing nothing, referring only to itself. The term turn has become increasingly popular to signify rethinking and renewal in the academic world. Thus to the linguistic turn, the pictorial turn and various others we would like to add the comparativist turn as a way to begin overcoming the fragilities and weaknesses of our field (Chryssochoou, 2001). The fragmentation which may be identified in various disciplines using comparative approaches is recognized by some as implying a sense of "methodological opportunism" (Przeworsky, 1996). The concurrent ambiguity and popularity of our field may be attributed to its flexibility and formability, a plasticity which provokes scholars like ourselves to call for a clarification of the concept of comparability, so as to allow for a better understanding of both the limitations, and potentialities of comparative research. This, we argue, is one of the ways to clarify comparison and avoid the "vaporous thinking" which infiltrates research approaches, particularly as they relate to education and European affairs.

It is our understanding - as we discuss elsewhere (Novoa \& Yariv, in press) - that a strengthening of the notion of "comparison in time" is the best approach to take if we wish to rescue comparative studies from being organized as "policy" rather than "research". Thus we call for a re-conceptualization of space-time relations, so as to build a historical understanding which will allow for a reconciliation between history and comparison. Alexander Stille refers 
to the idea that the "loss of historical memory" is hardly unique to our age (2002, p. xiii), but we believe it requires an added dimension in the contemporary context, calling for the construction of an interpretative space which is historically grounded. The definition of new zones of looking is, probably, the most important challenge for comparative research in the $21^{\text {st }}$ century. This implies a sophistication of our theories, binding together historical and comparative approaches so as to gather a new understanding of "problems" in the educational field. The word "reflexive" is typically employed to characterize our epoch, but it does not necessarily follow that people lead more conscious lives: "On the contrary, reflexive signifies not an increase of mastery and consciousness, but a heightened awareness that mastery is impossible" (Beck, 2001, p. 267). Paradoxically, consciousness of this impossibility is a precondition for the development of a critical understanding that strives to move beyond the superficiality diffused through media and expert-networks. According to Michel Foucault, the return to history makes sense because "the work of the intellect is to show that what is, does not have to be what it is” (cf. Lotringer, 1996, p. 359).

Coinciding with the attempt to create the European Educational Space is the development of a European Research Area: "Now is the time to bring our endeavors together and to build a research and innovation equivalent of the common market for goods and services" ${ }^{15}$. The rhetoric employed by EU officials is noticeably similar to that advanced to justify the European Educational Space (Banchoff, 2002). The two primary arguments, referring first, to a "common heritage" and second, to "unifying processes", are, in our opinion, flawed approaches to addressing this issue. The former, based in the claim that "Europeans share the same values", coincides with the identification of language diversity as a point of contention, rather than cohesion: "We cannot do much about languages - there are no plans for a single European language!” (Tent, 2001, pp. 9 \& 11). We do however find relevant arguments concerning mobility and scientific careers: "Mobility is an effective and well-known way of training researchers and spreading knowledge, (but) it is also true that in Europe today, a researcher's career unfolds by and large within a national framework" (Tent, 2001, p. 8). And even despite the dialogue surrounding the Bologna and Prague Conferences on the "European Higher Education Area", the same remains true for academic careers in European universities.

15 Welcome page, entitled "What is the European Research Area?” (http://europa.eu.int/comm/research/area). 
Nevertheless, one may expect further development of this Research Area, under two conditions: first, a focus on "interdisciplinary problem areas" in preference to "academic scientific disciplines” (Haller, 2001, p. 377), and second, greater attention given to “comparative research studies" (Kastrinos, 2001). Evolution in these terms will help in building a community of research on the basis of problems and comparative approaches, increasing the potential for critical thinking on the European Union. This will also have implications for the European Educational Space because it is impossible to build new educational perspectives and policies without a "critical mass" that allows for a deeper historical and theoretical understanding. For this, it is necessary to rethink the agenda of social research, so as to avoid what Ulrich Beck refers to as "zombie categories" - "living dead categories which govern our thinking but are not really able to capture the contemporary milieu” (2001a, p. 262). But it is also necessary to redefine historical and comparative methods, allowing for the distinct possibility that "Western forms of universality" will be judged "not only against the strengths of local knowledge systems, but against competing universalisms which are content with a less totalizing reach” (Lal, 2002, p. 13). Two works published at the turn of the millennium are essential in terms of situating "externally" European debates so as to allow room for new historical understandings. We have in mind Dipesh Chakrabarty's Provincializing Europe and Michael Hardt and Toni Negri's Empire. Despite taking different approaches and employing different theoretical lenses, both still contextualize center-periphery relations and the need to study Europe - or more broadly the West - as but one among many sources found in the past and future (cf. Argyrou, 2001). Such a sense of displacement is fundamental to understanding what is currently taking place in Europe.

Internally one cannot ignore the "battles for identity" or, as Zygmunt Bauman (2001) would have it for "identification". These are not specific to European contexts, but they acquire here a specific tonality. Giving attention to dynamics which are central with regard to "nation-Europe", Jock Young points out that: “Just as community collapses, identity is invented” (1999, p. 164). This same process is explained by Alexander Stille in his analysis of technological shifts: "The need for community, physical closeness, personal contact, and affection has not disappeared even if our lives have been considerably restructured” (2002, p. 339). Stille indicates that the search for meaning is inextricably bound to our own sense of our place in history. Though this endeavor may be at times excessive, it is exactly this which grants education a crucial role in the current redefinition of identities and affiliations. It is very much worth noting the fact that quite often, the difference in values is greater between generations than it is between nations (Kleinman, 2002, p. 214).

The "patrimony" upon which European integration should be built, in both the areas of education and research, will require a space for democratic discussion and deliberation: "The political public sphere can fulfill its function of perceiving and thematizing encompassing social problems only insofar as it develops out of the communication taking place among those 
who are potentially affected” (Habermas, 1996, p. 365). A decent society?, asked Maria Markus (2001). No doubt. But in order for this to be achieved it is necessary to avoid the production of "opacity" through a rhetoric of "transparence", and to move away from a kind of "fatalism" that brings a dangerous political climate as witnessed recently in so many elections on the continent. Resolution to an inexorable future brings us nowhere, and thus we must strive to steer a course away from manipulation by unelected groups, networks and institutions, and move further in the direction towards democracy. We close by reversing a popular metaphor and state: the "added value" of Europe resides in the presence of its citizens in politics and public life. And for this, we cannot dispense with education. 


\section{References}

Abbot, Kenneth \& Snidal, Duncan (2001). "International 'standards' and international governance”. Journal of European Public Policy, 8 (3), pp. 345-370.

Albert, Mathias (2002). "Governance and democracy in European systems: on systems theory and European integration”. Review of International Studies, 28 (2), pp. 293-309.

Anderson, Benedict (1991). Imagined Communities. London: Verso.

Andrew, Joe; Crook, Malcolm \& Waller, Michael, eds. (2000). Why Europe? Problems of culture and identity. London: Macmillan Press.

Argyrou, Vassos (2001). "Provincialising Europe - Reflections on questions of method and strategy". Social Anthropology, 9 (2), pp. 217-222.

Banchoff, Thomas (2002). "Institutions, Inertia and European Union Research Policy”. Journal of Common Market Studies, 40 (1), pp. 1-21.

Barnavi, Elie (2002). "European identity and ways of promoting it”. In Governance, Globalization and the European Union - Which Europe for Tomorrow? (Cavanna, Henry, ed.). Portland: Four Courts Press, pp. 87-94.

Bauman, Zygmunt (2000). Liquid Modernity. Cambridge: Polity Press.

Bauman, Zygmunt (2001). “The Great War of Recognition”. Theory, Culture \& Society, 18 (2-3), pp. 137-150.

Bauman, Zygmunt (2001a). “Consuming Life”. Journal of Consumer Culture, 1 (1), pp. 9-29.

Bauman, Zygmunt \& Tester, Keith (2001). Conversations with Zygmunt Bauman. Cambridge: Polity.

Beck, Ulrich (2001). “Interview with Ulrich Beck”. Journal of Consumer Culture, 1 (2), pp. 261-277.

Bellamy, Richard \& Warleigh, Alex, eds. (2001). Citizenship Governance in the European Union. London and New York: Continuum.

Benjamin, Walter (1968). Illuminations. New York: Harcourt, Brace and Jovanovich.

Bennett, Oliver (2001). Cultural Pessimism - Narratives of Decline in the Postmodern World. Edinburgh: Edinburgh University Press.

Berggreen-Merkel, Ingeborg (1999). “Towards a European educational area”. European Journal for Education Law and Policy, 3, pp. 1-7.

Bourdieu, Pierre (1994). Raisons pratiques - Sur la théorie de l'action. Paris: Éditions du Seuil.

Bourdieu, Pierre \& Wacquant, Loïc (2000). “La nouvelle vulgate planétaire”. Le Monde diplomatique, $\mathrm{n}^{0}$ 554, pp. 6-7.

Boyne, Roy (2001). "Cosmopolis and Risk - A conversation with Ulrich Beck". Theory, Culture \& Society, 18 (4), pp. 47-63. 
Breckenridge, Carol; Pollock, Sheldon; Bhabha, Homi \& Chakrabarty, Dipesh, eds. (2002). Cosmopolitanism. Durham, NC: Duke University Press.

Brubaker, Rogers (1996). Nationalism reframed - Nationhood and the national question in the New Europe. Cambridge: Cambridge University Press.

Casey, Lee \& Rivkin Jr., David (2001). “Europe in the Balance - The alarming undemocratic drift of the European Union”. Policy Review, 107, pp. 41-53.

Cederman, Lars-Erik (2001). "Nationalism and Bounded Integration: What it would take to construct a European Demos”. European Journal of International Relations, 7 (2), pp. 139-174.

Chakrabarty, Dipesh (2000). Provincializing Europe - Postcolonial thought and historical difference. Princeton: Princeton University Press.

Chryssochoou, Dimitris (2001). Theorizing European Integration. London: Sage Publications.

Clifford, James (1997). Routes - Travel and translation in the late twentieth century. Cambridge, MA: Harvard University Press.

Cram, Laura (2001). "Whither the Commission? Reform, renewal and the issue-attention cycle". Journal of European Public Policy, 8 (5), pp. 770-786.

Cram, Laura (2001a). “Governance 'to Go': Domestic actors, institutions and the boundaries of the possible”. Journal of Common Market Studies, 39 (4), pp. 595-618.

Cresswell, Tim (2001). “Mobilities - An introduction”. New Formations, 43, pp. 9-10.

Debord, Guy (1983). The society of the spectacle. Detroit: Black \& Red.

Decker, Frank (2002). "Governance beyond the nation-state - Reflections on the democratic deficit of the European Union”. Journal of European Public Policy, 9 (2), pp. 256-272.

Dinan, Desmond (1999). Ever Closer Union - An introduction to European integration. Boulder, Colorado: Lynne Rienner Publishers.

Eder, Klaus \& Giesen, Bernhard, eds. (2001). European Citizenship between National Legacies and Postnational Projects. Oxford: Oxford University Press.

Giddens, Anthony (2002). “A Third Way for the European Union?”. In The Pro-European Reader (Leonard, Dick \& Leonard, Mark, eds.). Hampshire: Palgrave, pp. 164-170.

Grass, Günter \& Bourdieu, Pierre (2002). “The ‘Progressive’ Restoration”. New Left Review, 14, pp. 63-77.

Green, Andy; Wolf, A. \& Leney, T. (1999). Convergence and divergence in European Education and Training Systems. London: Institute of Education - University of London.

Habermas, Jürgen (1996). Between facts and norms: Contributions to a discourse theory of law and democarcy. Cambridge: Polity Press.

Habermas, Jürgen (2001). "Why Europe needs a Constitution”. New Left Review, 11, pp. 5-26. 
Haller, Max, ed. (2001). The Making of the European Union - Contributions of the Social Sciences. Berlin: Springer-Verlag.

Hardt, Michael \& Negri, Antonio (2000). Empire. Cambridge, MA: Harvard University Press.

Hardt, Michael \& Negri, Antonio (2002). "The Global Coliseum: On Empire (interview by Nicholas Brown and Imre Szeman)”. Cultural Studies, 16 (2), pp. 177-192.

Hingel, Anders (2001). Education policies and European governance. Brussels: European Commission - Directorate-Generale for Education and Culture (http://europa.eu.int/comm/governance/areas/group12/contribution_education_en.pdf)

Hobsbawm, E.J. (1990). Nations and nationalism since 1780. Cambridge: Cambridge University Press.

Hodson, Dermot \& Maher, Imelda (2001). "The open method as a new method of governance: The case of soft economic policy co-ordination”. Journal of Common Market Studies, 39 (4), pp. 719-746.

Kastrinos, Nikos (2001). "Contribution of socio-economic research to the benchmarking of RTD policies in Europe”. Science and Public Policy, 28 (4), pp. 238-246.

Keller, Evelyn (1995). Refiguring Life - Metaphors of Twentieth-century Biology. New York: Columbia University Press.

Kleinman, Mark (2002). A European Welfare State? European Union social policy in context. Hampshire: Palgrave.

Lal, V. (2002). "Unhitching the disciplines: history and the social sciences in the new millennium". Futures, 34, pp. 1-14.

Le Magazine (Directorate-General for Education and Culture - European Commission), $\mathrm{n}^{\circ}$ 14, 2001.

Leonard, Mark (2002). "Network Europe”. In The Pro-European Reader (Leonard, Dick \& Leonard, Mark, eds.). Hampshire: Palgrave, pp. 139-149.

Lotringer, Sylvère, ed. (1996). Foucault Live - Collected Interviews, 1961-1984. New York: Semiotext(e).

Markus, Maria (2001). “Decent society and/or Civil society? Social Research, 68 (4), pp. 1011-1030.

Mazzoleni, G. (1995). “Towards a videocracy? Italian political communication at a turning point”. European Journal of Communication, 10, pp. 291-319.

Miller, Peter (2001). “Governing by numbers: Why calculative practices matter”. Social Research, 68 (2), pp. 379-396.

Moussis, Nicholas (1997). Handbook of European Union. Rixensart: European Study Service, $4^{\text {th }}$ edition.

Müller-Solger, Hermann (1999). "Education cooperation in the European Union at the threshold of the New Millennium”. European Journal for Education Law and Policy, 3, pp. 111-115.

Nevola, Gaspare (2001). "Education and political socialisation between national identity and European citizenship". In The Making of the European Union - Contributions of the Social Sciences (Haller, Max, 
ed.). Berlin: Springer-Verlag, pp. 331-359.

Novoa, Antonio (2000). “The restructuring of the European Educational Space”. In Educational Knowledge - Changing Relationships between the State, Civil Society, and the Educational Community (Popkewitz, Thomas, ed.). New York: Suny Press, pp. 31-57.

Novoa, Antonio (2002). "Ways of thinking about education in Europe”. In Fabricating Europe - The formation of an education space (Novoa, Antonio \& Lawn, Martin, eds.). Dordrecht: Kluwer Academic Publishers.

Novoa, Antonio \& Yariv-Mashal, Tali (in press). Comparative Research in Education: A mode of governance or a historical inquiry?

Peterson, John (2001). “The choice for EU theorists: Establishing a common framework for analysis”. European Journal of Political Research, 39, pp. 289-318.

Popkewitz, Thomas; Lindblad, Sverker \& Strandberg, Johanna (1999). Review of Research on Education Governance and Social Integration and Exclusion. Uppsala: Department of Education Uppsala Reports of Education 35.

Przeworski, A. (1996). “The role of theory in comparative politics: A symposium”. World Politics, 48 (1), pp. 1-49.

Reding, Viviane (2000). Education in the $21^{\text {st }}$ century: Education for the knowledge economy (Conference of the Asia-Europe Foundation, Luxembourg, 2 May 2000).

Reding, Viviane (2000a). Education: The new challenges (European Business Summit, Brussels, $10^{\text {th }}$ June 2000).

Roberts, Ivor \& Springer, Beverly (2001). Social Policy in the European Union - Between harmonization and national autonomy. Boulder and London: Lynne Rienner Publishers.

Robinson, William (2001). "Social theory and globalization: The rise of a transnational state”. Theory and Society, 30 (2), pp. 157-200.

Rose, Nikolas (1999). Powers of freedom. Cambridge: Cambridge University Press.

Schnapper, Dominique (2002). “Citizenship and national identity”. Nations and nationalism, 8 (1), pp. $1-14$.

Schudson, Michael (2002). “The News Media as Political Institutions”. Annual Review of Political Science, 5, pp. 249-269.

Shore, Cris (2000). Building Europe - The cultural politics of European integration. London and New York: Routledge.

Sisson, Keith \& Marginson, Paul (2001). Benchmarking and the "Europeanisation" of social and employment policy. Sussex: ESRC “One Europe or Several” Programme - Briefing note 3/01.

Smith, Anthony (1991). National identity. Reno: University of Nevada Press.

Smith, Anthony (2000). The Nation in History - Historiographical debates about ethnicity and nationalism. Hanover: University Press of New England. 
Stille, Alexander (2002). The Future of the Past. New York: Farrar, Strauss and Giroux.

Sweet, Alec; Sandholtz, Wayne \& Fligstein, Neil, eds. (2001). The Institutionalization of Europe. Oxford: Oxford University Press.

Tent, H. (2001). Towards a European Research Area Open to the World. Special lecture given at the Annual Meeting and Science Innovation Exhibition (San Francisco, February 15-20) (website europa.eu.int/comm/research/area).

Van Ham, Peter (2001). European Integration and the Postmodern Condition - Governance, democracy, identity. London and New York: Routledge.

Van Heffen, Oscar; Kickert, Walter \& Thomassen, Jacques, eds. (2000). Governance in Modern Society. Dordrecht: Kluwer Academic Publishers.

Verstraete, Ginette (2001). “Technological frontiers and the politics of mobilities”. New Formations, 43, pp. 26-43.

Wagner, Peter (2001). Theorizing Modernity - Inescapability and Attainability in Social Theory. London: Sage.

Wallace, Helen (2001). "The Changing Politics of the European Union: An Overview”. Journal of Common Market Studies, 39 (4), pp. 581-594.

Wallace, Helen, ed. (2001a). Interlocking Dimensions of European Integration. Hampshire and New York: Palgrave.

White, Hayden (1987). The content of the form: narrative discourse and historical representation. Baltimore: John Hopkins University Press.

Wielemans, Willy (2000). "European educational policy on shifting sand?”. European Journal for Education Law and Policy, 4, pp. 21-34.

Young, Jock (1999). The exclusive society. London: Sage Publications.

\section{European Union Documents}

1993 - Green Paper European Dimension of Education.

1995 - White Paper Teaching and Learning: towards the Learning Society.

1997 - Study Group on Education and Training Accomplishing Europe through Education and Training.

1997 - Communication from the Commission Towards a Europe of Knowledge.

1998 - Report from the Commission Learning for active citizenship: A significant challenge in building a Europe of knowledge.

2000 - Memorandum on Lifelong Learning.

2000 - Lisbon European Council: Presidency Conclusions (March 23-24). 
2000 - “Annexes to the European Council conclusions”, Bulletin EU, 12-2000.

2000 - European Report on Quality of School Education.

2000 - Decision from the Commission - Towards a European Research Area.

2001 - Stockholm European Council: Presidency Conclusions (March 23-24).

2001 - White Paper on European Governance.

2001 - Report from the Commission The concrete future objectives of education systems.

2001 - $2391^{\text {st }}$ Education Council meeting (Brussels, November 29).

2001 - "Education - Commission communication to Parliament, the Council, the Economic and Social Committee and the Committee of the Regions entitled Making a European area of lifelong learning a reality”, Bulletin EU, 11-2001.

2002 - Detailed work programme on the follow-up of the objectives of education and training systems in Europe.

$2002-2408^{\text {th }}$ Education Council meeting (Brussels, February 14).

2002 - Barcelona European Council: Presidency conclusions (March 15-16).

$2002-2430^{\text {th }}$ Education Council meeting (Brussels, May 30).

2002 - Education and lifelong learning - Council Resolution (May 30). 